\title{
The dietary level of selenite and selenized yeast influences the concentrations of selected fatty acids in the abdominal fat and brain of rats*
}

\author{
M. Czauderna1, J. Kowalczyk, K.A. Krajewska, J.P. Michalski
}

The Kielanowski Institute of Animal Physiology and Nutrition, Polish Academy of Sciences 05-110 Jabłonna, Poland

(Received 3 February 2010; revised version 18 February 2010; accepted 1 March 2010)

\begin{abstract}
The effects of supplementing diets with a mixture of conjugated linoleic acid (CLA) isomers (CLAmix) and/or selenium as $\mathrm{Na}_{2} \mathrm{SeO}_{3}(\mathrm{SeIV})$ or selenized yeast (SeY) on the growth performance of rats and on the contents of some fatty acids (FA) in their abdominal fat and brains were investigated. The study was performed on 80 female Wistar rats (Hsd Brl Han: WIST), 8 weeks of age with an initial body weight of $195.4 \pm 0.8 \mathrm{~g}$. Each group numbered 8 rats. During the 7 -day preliminary period the rats were fed a standard Labofeed $\mathrm{H}$ diet at a sub-maintenance level. Next, for 6 weeks the rats were fed ad libitum on the experimental diets supplemented with CLAmix, $0.2 \mathrm{ppm}$ Se or 0.5 ppm Se as SeIV ( ${ }_{\mathrm{L}} \mathrm{SeIV}$ or ${ }_{\mathrm{H}} \mathrm{SeIV}$, respectively) and $\mathrm{SeY}\left({ }_{\mathrm{L}} \mathrm{SeY}\right.$ or ${ }_{\mathrm{H}} \mathrm{SeY}$, respectively). The rats were sacrificed at the end of the six-week experimental period. The diets enriched in ${ }_{\mathrm{H}} \mathrm{SeIV},{ }_{\mathrm{L}} \mathrm{SeY}$, or ${ }_{\mathrm{H}} \mathrm{SeY}$ increased the body weight gain (BWG) compared with the control rats, while the dietary CLAmix had a negligible effect on BWG in comparison with the control group. The addition of CLAmix to the diet enriched in Se, regardless of the level of extra Se and its chemical form, showed a negligible influence on the BWG in animals compared with rats fed the diet containing only ${ }_{\mathrm{L}} \mathrm{SeIV},{ }_{\mathrm{H}} \mathrm{SeIV}$, ${ }_{\mathrm{L}} \mathrm{SeY}$ or ${ }_{\mathrm{H}} \mathrm{SeY}$, respectively. Dietary ${ }_{\mathrm{L}} \mathrm{SeIV}$ resulted in a decrease in the content of saturated fatty acids (SFA), atherogenic SFA (A-SFA), thrombogenic SFA (T-SFA), mono- (MUFA), poly- (PUFA) unsaturated fatty acids, PUFAn-3, PUFAn-6, $c 9 \mathrm{C} 18: 1, c 9 c 12 \mathrm{C} 18: 2$ (LA), $c 6 c 9 c 12 \mathrm{C} 18: 3 \gamma$-LNA), $c 9 c 12 c 15 \mathrm{C} 18: 3$ ( $\alpha$-LNA) and the sum of FA in the fat of rats. The diets enriched in CLAmix, $\mathrm{HeIV}$, ${ }_{\mathrm{L}} \mathrm{SeY}$ or ${ }_{\mathrm{H}} \mathrm{SeY}$ generally exhibited a smaller influence on the level of these FA in the fat compared with rats fed the diet with ${ }_{\mathrm{L}}$ SeIV. The diet with ${ }_{\mathrm{L}}$ SeIV had a negligible influence on the content of long-chain PUFAn-3 and n-6 (LPUFAn-3 and LPUFAn-6) in the fat compared with the control rats. The diet with ${ }_{\mathrm{L}} \mathrm{SeIV}$ numerically or statistically increased the ratio of PUFA/SFA, MUFA/
\end{abstract}

\footnotetext{
${ }^{*}$ Supported in part by the Ministry for Science and Information, Grant No. N N311 336433

${ }^{1}$ Corresponding author: e-mail: m.czauderna@ifzz.pan.pl
} 
SFA, UFA/SFA, and PUFA/FA in the fat compared with the control group. Other experimental diets resulted in inconsistent and negligible changes of these ratios in the fat compared with the control group. The diets with CLAmix or Se (as SeIV or SeY) reduced the content of C14:0, C16:0, C18:0, c9C18:1, LA, $\alpha \mathrm{LNA}, c 11 c 14 c 17 \mathrm{C} 20: 3, c 8 c 11 c 14 \mathrm{C} 20: 3, c 5 c 8 c 11 c 14 \mathrm{C} 20: 4, c 7 c 10 c 13 c 16 c 19 \mathrm{C} 22: 5$, $c 4 c 7 c 10 c 13 c 16$ c19C22:6, SFA, A-SFA, T-SFA, MUFA, PUFAn-3, LPUFAn-3, PUFAn-6 and LPUFAn-6 in the brain compared with the control group. The diet enriched in CLAmix and Se (as ${ }_{\mathrm{L}} \mathrm{SeIV},{ }_{\mathrm{H}} \mathrm{SeIV},{ }_{\mathrm{L}} \mathrm{SeY}$ or ${ }_{\mathrm{H}} \mathrm{SeY}$ ) decreased the content of these FA in the brain (the interactions: $\mathrm{P}<0.01)$. The ratio of PUFA/SFA, MUFA/SFA, UFA/FA and PUFA/FA was higher $(\mathrm{P}<0.01)$ in the brain of rats fed the diet with the one additive than in the control group. The diet enriched in CLAmix or Se (as SeIV or SeY) decreased $\Delta 9$-desaturase capacity in comparison with the control rats; interaction effects of CLAmix x Se (as ${ }_{H} \mathrm{SeIV},{ }_{\mathrm{L}} \mathrm{SeY}$ or $\left.{ }_{\mathrm{H}} \mathrm{SeY}\right)$ were found $(\mathrm{P}<0.01)$. Feeding rats with the diet enriched in ${ }_{\mathrm{H}} \mathrm{SeIV}$ or ${ }_{\mathrm{H}} \mathrm{SeY}$ with or without CLAmix improved the nutritive value of the abdominal fat by increasing the content of LPUFAn-3, while the PUFAn-6/PUFAn-3 ratio decreased, particularly in the fat of rats fed the diet containing SeY. Finding that diets enriched in CLAmix and ${ }_{\mathrm{L}} \mathrm{SeY}$ or ${ }_{\mathrm{H}} \mathrm{SeIV}$ most effectively increased the content of CLA isomers in the abdominal fat and efficiently elevated body weight accretion and feed conversion efficiency in rats is valuable information for nutritionists carrying out research to improve the value of food derived from monogastric animals for human health.

KEY WORDS: rats, selenized yeast, selenite, CLA isomers, fatty acids, abdominal fat, brain

\section{INTRODUCTION}

Inorganic forms of selenium (Se) such as selenite and selenate are not normally major dietary constituents, although selenite (SeIV) has long been accepted as the principal source of Se for farm animal feeds and food supplements because it is inexpensive. Concerns have arisen, however, regarding the environmental impact of Se in agricultural waste water, especially on drinking water (Ohlendorf, 2002). In the meantime, evidence has accumulated that Se-methionine (Se-Met) is more effectively assimilated and retained in animal bodies than Se from inorganic sources (Dumont et al., 2006; Navarro-Alarcon and Cabrera-Vique, 2008). Replacing SeIV with Se-Met, the principal form of Se present in selenium-enriched yeast (SeY) or plants, allows more effective use of dietary Se and decreases the burden on the environment. Currently, SeY is the primary Se dietary supplement and is the most attractive source of Se-Met due to its ability to act as a precursor for Se-containing protein synthesis in farm animals (Hinojosa et al., 2006). Furthermore, Se-Met in $\mathrm{SeY}$ is stable even at higher temperatures (Dumont et al., 2006).

Our investigations on rats and other studies have documented that the content of polyunsaturated fatty acids (PUFA), especially in serum cholesterol esters and phospholipids, was positively correlated with the dietary Se concentration (Crespo et al., 1995; Czauderna et al., 2003, 2004). Indeed, Se, an essential trace element for mammals, has been found to be an integral part of the active site 
of cytosolic and mitochondrial glutathione peroxidases, as well as phospholipid hydroperoxide glutathione peroxidase (cGPx) (Wolffram, 1999; Zagrodzki et al., 2000, 2001; Arteel and Sies, 2001). Investigations have established that phospholipid hydroperoxide cGPx acts more directly in protecting PUFA from peroxidation damage (Crespo et al., 1995). Moreover, our early studies using rats documented that the concentration of conjugated linoleic acid (CLA) isomers increased in femoral muscles of rats fed a diet enriched in selenate and CLA isomers compared with a diet having only CLA isomers (Czauderna et al., 2003, 2004). This finding that selenate and CLA isomers fed to rats considerably increase the level of CLA isomers, non-CLA fatty acids containing double bonds, and other PUFA in fat tissues of animals is valuable information for nutritionists carrying out research to improve the health value for humans of food derived from monogastric farm animals. Therefore, it can be hypothesized that the interactions between CLA isomers and other chemical forms of Se (as SeIV and $\mathrm{SeY}$ ) stimulated the accumulation of CLA isomers in fat tissues of animals, as well as exerted a protective effect against peroxidation damage and/or catabolism on CLA isomers. Thus, the major objective of our study was to investigate the influence of different Se-compounds (as SeIV or SeY) in a diet enriched in CLA isomer mixture (CLAmix) on the deposition of fatty acids (FA) in rat tissues rich in FA. Considering the above, we analysed the effect of experimental diets on FA profiles in the abdominal fat tissue and brains of rats. In our pilot studies, laboratory rats were used as model animals for domestic monogastric animals like pigs. Moreover, the use of rats significantly lowered the cost of our preliminary investigations.

\section{MATERIAL AND METHODS}

\section{Animals, housing, diets, sampling and analytical methods}

The experiment was carried out on 80 female rats (Wistar, Hsd Brl Han: WIST), 8 weeks of age with an initial body weight of $195.4 \pm 0.8 \mathrm{~g}$. The rats were housed and handled in accordance with protocols approved by the Local Animal Care and Use Committee (The Agricultural University of Warsaw, Poland). The rats were maintained individually in plastic cages at a temperature of $22 \pm 1^{\circ} \mathrm{C}$ with a $12 \mathrm{~h}$ light-dark cycle and relative humidity of 50-60\%. Each group comprised eight rats. The animals were fed the standard Labofeed $\mathrm{H}$ diet produced by the Feeds and Concentrates Production Plant in Kcynia (Poland), according to the recommendations of Pastuszewska et al. (2000). For our investigations, the standard Labofeed $\mathrm{H}$ diet was enriched in $0.2 \mathrm{ppm}$ Se as selenite (Table 1). During 
The rats were killed at the end of the six-week experiment. The brain and abdominal fat tissues were removed, weighed, and frozen. The concentrations of FA in the rat brains were calculated based on freeze-dried brain samples, while the concentration of FA in the abdominal fat tissue was based on the fresh mass of fat tissue samples. Lipids in brain tissue $(\sim 25 \mathrm{mg})$ and abdominal fat $(\sim 8 \mathrm{mg})$ samples were saponified (Czauderna et al., 2007) followed by gentle base- and acid-catalysed methylations of free FA (Czauderna et al., 2007). All brain and fat tissues of rats were analysed individually.

\section{Reagents and chemicals}

All chemicals were analytical grade and organic solvents were of HPLC grade. Dichloromethane (DCM), $\mathrm{KOH}, \mathrm{NaOH}, \mathrm{Na}_{2} \mathrm{SO}_{4}$ and conc. $\mathrm{HCl}$ were purchased from POCH (Gliwice, Poland). Acetonitrile, methanol, and n-heptane $(99 \%, \mathrm{GC})$ were supplied by Lab-Scan (Ireland), while the CLA isomer mixture (2.1\% $t \mathrm{tCLA}$, 7.1\% c11t13CLA, 40.8\% c9t11CLA, 41.3\% t10c12CLA, 6.7\% c8t10CLA and $2.0 \% c c$ CLA) by Industrial Chemistry Research Institute (Warsaw, Poland). The concentration ratio $\left(\mathrm{R}_{c 9 t 11 \mathrm{CLA} / t 10 c 72 \mathrm{CLA}}\right)$ of $c 9 t 11 \mathrm{CLA}$ to $t 10 c 12 \mathrm{CLA}$ in the dietary CLA isomer mixture was 0.9879 . Fatty acid methyl ester (FAME) standards and $25 \% \mathrm{BF}_{3}$ in methanol were purchased from Supelco and Sigma (USA). Water used for the preparation of mobile phases and chemical reagents was prepared using an ElixTM water purification system (Millipore). The mobile phases were filtered through a $0.45 \mu \mathrm{m}$ membrane filter (Millipore).

\section{Chromatographic equipment}

The analyses of all FAME in brain and fat tissues were performed on a SHIMADZU GC-MS-QP2010 Plus EI equipped with a BPX70 fused silica capillary column $(120 \mathrm{~m} \times 0.25 \mathrm{~mm}$ i.d. $\times 0.25 \mu \mathrm{m}$ film thickness; SHIM-POL, quadrupole mass selective (MS) detector (Model 5973N) and injection port. Helium as the carrier gas operated at a constant pressure $(223.4 \mathrm{kPa})$ and flow rate of $1 \mathrm{ml} / \mathrm{min}$. Injector and MS detector temperatures were maintained at 200 and $240^{\circ} \mathrm{C}$, respectively. The total FAME profile in a one $\mu 1$ sample at a split ratio of 10:1 was determined using the column temperature gradient programme as previously described (Czauderna et al., 2009). FAME identification was validated based on electron impact ionization spectra of FAME and compared with authentic FAME standards and NIST 2007 reference mass spectra library.

Separation of non-methylated CLA isomers in hydrolysates was performed by use of two analytical ion-exchange columns loaded with silver ions $(250 \times 4.6 \mathrm{~mm}$ ChromSpher 5- $\mu \mathrm{m}$ Lipids column; Chrompack, the Netherlands), connected in a series, with a guard column of $10 \times 3 \mathrm{~mm}$ containing the same stationary phase (Czauderna et al., 2007). A Waters (Milford, MA USA) HPLC system was used. 
This system comprised an alliance separation module (model 2690, Waters) and a Waters 996 photodiode array detector (DAD). The mobile phase of $1.6 \%$ acetic acid and $0.0125 \%$ acetonitrile in n-hexane was chosen as the optimum mobile phase for fractionation of CLA isomers (Czauderna et al., 2007). Isocratic elution was performed as described by Czauderna et al. (2007).

\section{Statistical analyses}

Results are presented as means \pm SD of individually analysed samples of brain and abdominal fat. Statistical analyses of the effects of dietary CLAmix and Se (as SeIV or SeY) were conducted using the non-parametric Mann-Whitney U test for comparing independent experimental groups. Differences were considered significant at ${ }^{a, b} \mathrm{P}<0.05$ or ${ }^{\mathrm{A}, \mathrm{B}} \mathrm{P}<0.01$, while at ${ }^{\alpha, \beta} \mathrm{P}<0.1$ differences were taken as tendencies. Statistical analyses of the interaction between CLAmix and Se (as SeIV or SeY) were performed using two-factorial ANOVA analysis. For statistical analyses the program Statistica ver. 6 (Statistica by StatSoft, 2002. Web: www. statsoft.pl) were used.

\section{RESULTS AND DISCUSSION}

The effect of the experimental diets on body weight gain, feed intake and brain mass. During the 7-day preliminary period of sub-maintenance feeding on the un-supplemented Labofeed $\mathrm{H}$ diet, all rats lost about $15 \mathrm{~g}$ body weight (Table 2). As expected, no macroscopic lesions or pathological changes were found in the liver, or in any other organs of the rats fed the diets enriched in CLAmix and/or Se (as SeIV or SeY). Indeed, diets containing up to $2 \mathrm{mg}$ Se per $\mathrm{kg}$ would not be toxic for rodents (e.g. rats or mice) (Czauderna et al., 2009; McDowell et al., 2005). Only chronic dietary intake of Se-compounds, selenite in particular, at rates of more than $5 \mathrm{mg}$ Se per $\mathrm{kg}$ can be hepatotoxic and teratogenic in humans and animals (Tinggi, 2003). The obtained data indicate that the rats fed the experimental diets enriched in $0.5 \mathrm{ppm}$ SeIV, $0.2 \mathrm{ppm}$ $\mathrm{SeY}$ or $0.5 \mathrm{ppm} \mathrm{SeY}$ increased their body weight gain (BWG) compared with the control rats, whereas the addition of $1.5 \%$ CLAmix to the diet revealed a negligible effect on BWG in comparison with the control group. The current results documented that dietary 0.2-0.5 ppm Se as SeY or 0.5 ppm Se as SeIV upregulated anabolic processes in rats, although the lower level of SeY in the diet $(\mathrm{S} \mathrm{SeY})$ most effectively stimulated body weight accretion in animals (Table 2). On the other hand, the higher dietary concentration of inorganic Se (i.e. $\left.{ }_{\mathrm{H}} \mathrm{SeIV}\right)$ more efficiently stimulated anabolic processes than the lower level of 
Table 2. Dietary effects of 1.5\% CLA isomer mixture (CLAmix) and selenite (SeIV) or selenized yeast $(\mathrm{SeY})$ on the body weight gain $(\mathrm{BWG})^{1}$, total feed intake (per a rat), feed conversion efficiency (FCE; $\mathrm{g}$ body weight gain/g feed intake) ${ }^{1}$, and brain fresh mass ( $\mathrm{g}$ ) of rats after 6 weeks feeding with experimental diets ${ }^{2}$

\begin{tabular}{|c|c|c|c|c|c|c|c|}
\hline \multirow{2}{*}{ Group } & \multirow{2}{*}{ Additives } & \multicolumn{2}{|c|}{ Body weight, g } & \multirow{2}{*}{$\begin{array}{c}\text { BWG } \\
\mathrm{g}\end{array}$} & \multirow{2}{*}{$\begin{array}{c}\text { Total } \\
\text { feed } \\
\text { intake, } \mathrm{g}\end{array}$} & \multirow{2}{*}{$\begin{array}{c}\text { FCE } \\
\mathrm{g} / \mathrm{g}\end{array}$} & \multirow{2}{*}{$\begin{array}{c}\text { Brain } \\
\text { mass }^{4} \\
\mathrm{~g}\end{array}$} \\
\hline & & initial & adapted $^{3}$ & & & & \\
\hline$\overline{\text { Control }}$ & - & 196.0 & 180.4 & $50.0^{\mathrm{ab} \alpha}$ & $742.3^{\alpha}$ & 0.068 & $1.869^{\mathrm{a}}$ \\
\hline SeIV & $0.2 \mathrm{ppm}$ SeIV & 194.7 & 176.9 & 53.5 & 755.8 & 0.079 & 1.813 \\
\hline $\mathrm{SeIV}$ & $0.5 \mathrm{ppm}$ SeIV & 195.7 & 180.1 & $57.1^{\alpha}$ & 766.9 & 0.075 & 1.804 \\
\hline${ }^{\mathrm{H}} \mathrm{SeY}$ & $0.2 \mathrm{ppm} \mathrm{SeY}$ & 196.7 & 179.2 & $58.1^{\mathrm{a}}$ & 763.4 & $0.076^{\mathrm{a}}$ & 1.832 \\
\hline${ }_{\mathrm{SeY}}^{\mathrm{L}}$ & $0.5 \mathrm{ppm} \mathrm{SeY}$ & 195.0 & 177.3 & $55.6^{\mathrm{b}}$ & 740.4 & $0.075^{\mathrm{c}}$ & 1.768 \\
\hline CLA & CLAmix & 196.5 & 181.7 & $51.9^{\text {cde }}$ & $718.7^{a \alpha}$ & $0.069^{\mathrm{b}}$ & $1.709^{\mathrm{a} \alpha}$ \\
\hline${ }_{\mathrm{L}} \mathrm{SeIV}_{\mathrm{CLA}}$ & $\begin{array}{l}0.2 \text { ppm SeIV } \\
\text { CLAmix }\end{array}$ & 195.3 & 180.3 & 54.8 & 728.3 & 0.075 & 1.804 \\
\hline${ }_{\mathrm{H}} \mathrm{SeIV}_{\mathrm{CLA}}$ & $\begin{array}{l}0.5 \text { ppm SeIV } \\
\text { CLAmix }\end{array}$ & 194.7 & 177.0 & $59.9^{\mathrm{ex}}$ & 742.7 & 0.081 & 1.780 \\
\hline${ }_{\mathrm{L}} \mathrm{SeY}_{\mathrm{CLA}}$ & $\begin{array}{l}0.2 \text { ppm SeY } \\
\text { CLAmix }\end{array}$ & 194.9 & 178.3 & $56.1^{\mathrm{d}}$ & $771.8^{\mathrm{a}}$ & $0.073^{\mathrm{abx}}$ & 1.758 \\
\hline${ }_{\mathrm{H}} \mathrm{SeY}_{\mathrm{CLA}}$ & $\begin{array}{l}0.5 \text { ppm SeY } \\
\text { CLAmix }\end{array}$ & 194.7 & 177.4 & $54.6^{\mathrm{c}}$ & 719.1 & $0.076^{\text {cy }}$ & $1.799^{\alpha}$ \\
\hline
\end{tabular}

${ }^{1}$ FCE and BWG after feeding for 6 weeks with the experimental diets enriched in CLAmix with or without $\mathrm{Se}$ (as ${ }_{\mathrm{L}} \mathrm{SeIV},{ }_{\mathrm{H}} \mathrm{SeIV},{ }_{\mathrm{L}} \mathrm{SeY}$ or ${ }_{\mathrm{H}} \mathrm{SeY}$ ); ${ }^{2}$ means in columns sharing the same letter are significantly different: ${ }^{a, b} \mathrm{P}<0.05$ and ${ }^{\mathrm{A}, \mathrm{B}} \mathrm{P}<0.01 ;{ }^{\alpha, \beta} \mathrm{P}<0.1$ differences were taken as tendencies; interactions of CLAmix $x_{L}$ Se and CLAmix $x_{H}$ Se (Se as SeIV or SeY), significant at ${ }^{x, y} \mathrm{P}<0.05$ and ${ }^{\mathrm{X}} \mathrm{Y} \mathrm{P}<0.01$, respectively; ${ }^{3}$ the body weight $(\mathrm{g})$ of individually adapted rats after 7 days of submaintenance feeding ( $9 \mathrm{~g}$ the Labofeed $\mathrm{H}$ diet per day per rat); the average body weight of all adapted rats: $179.0 \pm 6.1 \mathrm{~g}$; ${ }^{4}$ average masses of fresh brains of rats

SeIV in the diet $\left({ }_{\mathrm{L}} \mathrm{SeIV}\right)$. The current results thus show that Se bioavailability is affected by its chemical form; generally, dietary organic Se compounds are more bioavailable than the inorganic forms of Se (like selenite or selenate) (Thomson, 2004). Our previous studies (Czauderna et al., 2003, 2004) demonstrated that 2 $\mathrm{ppm}$ of Se as selenate in the diet decreased body weight accretion, as well as feed conversion efficiency in rats. Thus, the present results and our previous studies suggest that diets containing at least 2 ppm Se catalyse hydrosulphide oxidation, which exerts an inhibitory effect on protein biosynthesis (Navarro-Alarcon and Cabrera-Vique, 2008).

The addition of CLAmix to the diet enriched in Se, regardless of the level of extra Se and its chemical form, showed a negligible influence on the BWG in animals compared with rats fed the diet enriched in Se as ${ }_{\mathrm{L}} \mathrm{SeIV},{ }_{\mathrm{H}} \mathrm{SeIV},{ }_{\mathrm{L}} \mathrm{SeY}$ or ${ }_{\mathrm{H}} \mathrm{SeY}$, respectively. On the other hand, the addition of CLAmix to the diet tended to decrease $(\mathrm{P}<0.1)$ feed intake compared with the control group, whereas the diet with $\mathrm{Se}$ (as SeIV or SeY) slightly increased it in comparison with the control rats, although no significant differences in these values were found. The diet containing CLAmix and ${ }_{\mathrm{L}} \mathrm{SeY}$ resulted in the highest increase of feed intake among the 
experimental diets, although this value was statistically higher $(\mathrm{P}<0.05)$ compared with the diet enriched only in CLAmix.

The current results are supported by our previous studies (Czauderna et al., 2003) showing that the dietary CLA isomer mixture efficiently reduces feed intake, as well as by other studies demonstrating that it increases energy expenditure (Hur et al., 2007; Park and Pariza, 2007). On the other hand, the addition of SeIV or $\mathrm{SeY}$ to the diet containing CLAmix increased the feed conversion efficiency (FCE) compared with the diet enriched in only CLAmix (Table 2). Thus, our investigation indicate that dietary SeIV and SeY showed a similar effect on feed intake and FCE as the addition of selenate to the diet for rats (Czauderna et al., 2003, 2004). Considering the above, we argue that dietary Se-compounds diminish the effect of CLA isomers on FCE in rats.

Unexpectedly, all experimental diets, especially the diet with CLAmix $(\mathrm{P}<0.05)$, resulted in a decrease in the mass of brains of experimental rats in comparison with the control group. Thus, the current results are consistent with our previous studies on rats fed diets enriched in selenate with or without CLA isomers (Czauderna et al., 2003). Our studies documented that dietary selenate (Czauderna et al., 2003), SeIV and SeY revealed a similar effect on the brain mass of rats. Moreover, the current results are in agreement with our previous studies in which dietary CLA isomer mixture decreased the brain mass of rats (Czauderna et al., 2003).

The effect of the experimental diets on the fatty acid profile in the abdominal. In the current investigation, the fatty acid composition of abdominal fat (Tables 3 and 4 ) and brain tissue (Tables 5 and 6 ) of rats was affected by feeding the diet enriched in CLAmix with or without Se, regardless of its level and chemical form (i.e. ${ }_{\mathrm{L}} \mathrm{SeIV},{ }_{\mathrm{H}} \mathrm{SeIV},{ }_{\mathrm{L}} \mathrm{SeY}$ or ${ }_{\mathrm{H}} \mathrm{SeY}$ ).

Data from our study documented that dietary $0.2 \mathrm{ppm}$ Se as SeIV resulted in a significant decrease in the concentration of saturated fatty acids (SFA), atherogenic SFA (A-SFA), thrombogenic SFA (T-SFA), mono- (MUFA), poly(PUFA) unsaturated fatty acids, PUFAn-3, PUFAn-6, the sum of fatty acids ( $\Sigma F A)$ and $c 9 \mathrm{C} 18: 1, c 9 c 12 \mathrm{C} 18: 2$ (LA), $c 6 c 9 c 12 \mathrm{C} 18: 3(\gamma$-LNA) and $c 9 c 12 c 15 \mathrm{C} 18: 3$ $(\alpha$-LNA) in the abdominal fat of rats (Tables 3 and 4$)$. On the other hand, the diets enriched only in CLAmix, $0.5 \mathrm{ppm}$ Se as SeIV, 0.2 or $0.5 \mathrm{ppm}$ Se as SeY exhibited a generally smaller influence on the concentration of these fatty acids in the fat compared with rats fed the diet with $0.2 \mathrm{ppm}$ Se as SeIV. The diet with $0.2 \mathrm{ppm} \mathrm{Se}$ as SeIV revealed a negligible influence on the values of atherogenic (A-SFA ${ }_{\text {index }}$ ) and thrombogenic (T-SFA ${ }_{\text {index }}$ ) indexes, as well as $\Delta 9-, \Delta 6-, \Delta 4$-desaturases and elongase indexes in the abdominal fat; consequently, dietary $0.2 \mathrm{ppm}$ Se as SeIV revealed a negligible influence on the concentration of n-3 and n-6 long-chain polyunsaturated fatty acids (LPUFAn-3 and LPUFAn-6) in the fat compared with the control rats (Table 4). 


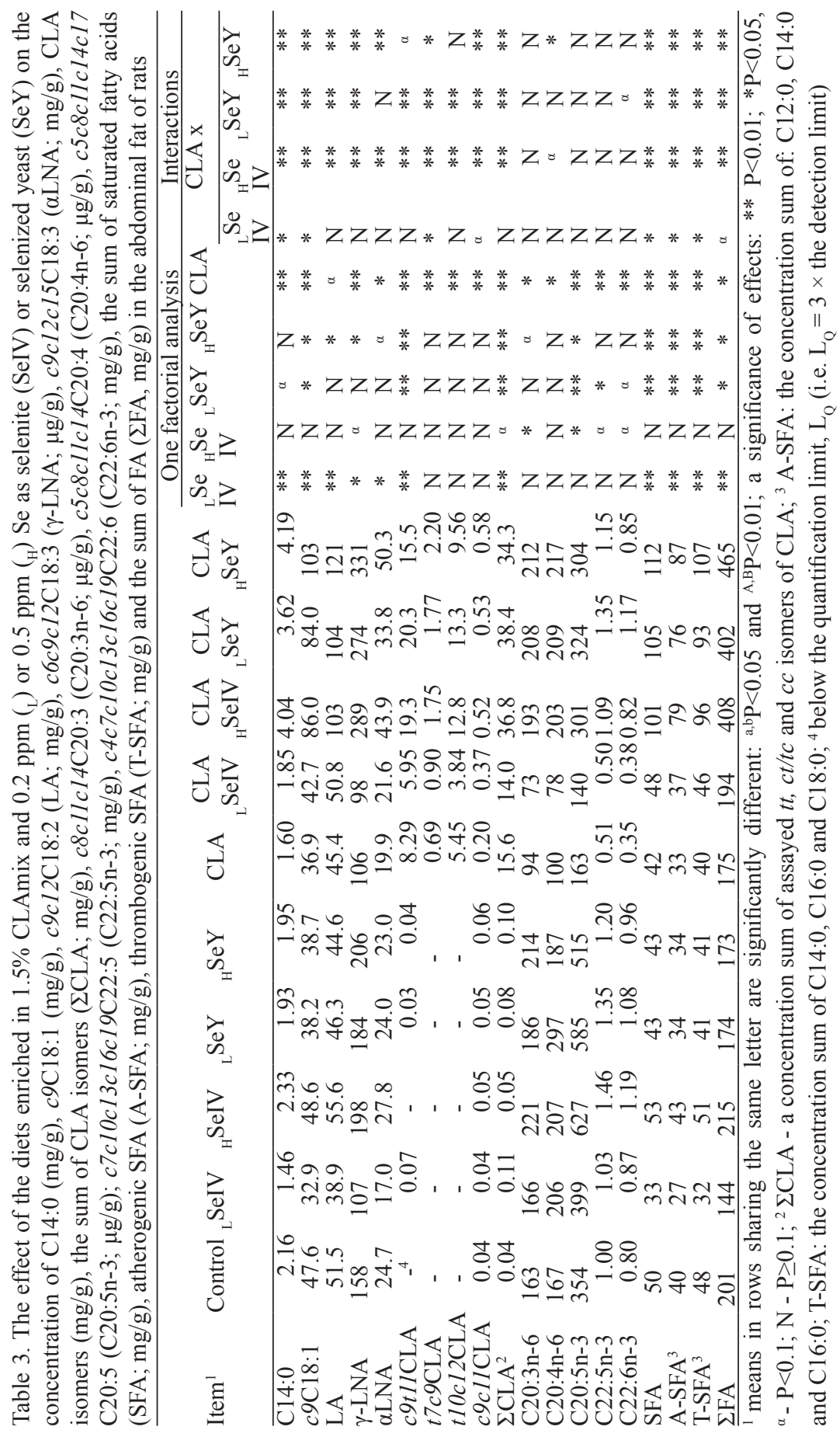




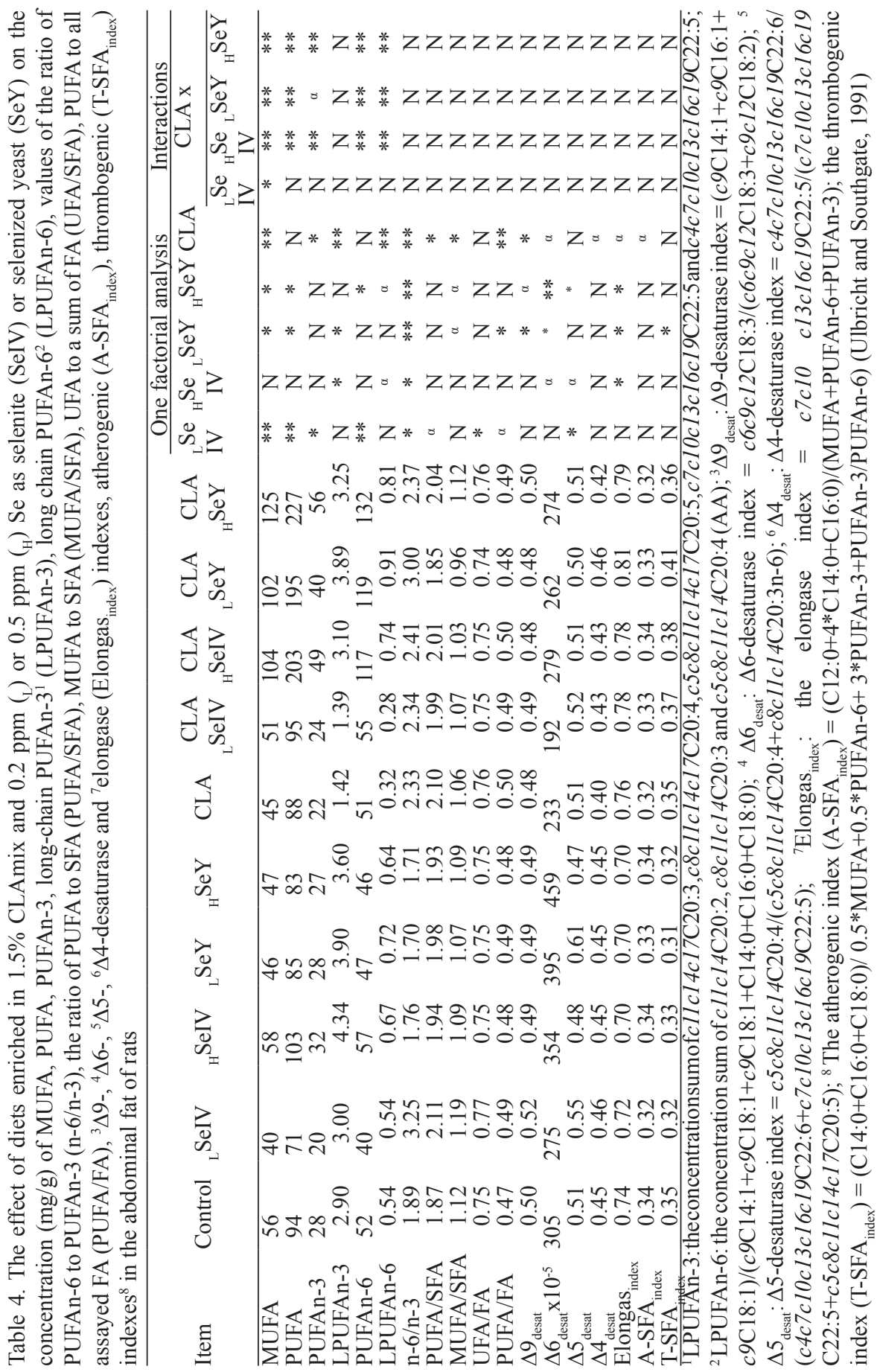


The addition of CLAmix to the diet significantly increased $(\mathrm{P}<0.01)$ the concentration of CLA isomers in the abdominal fat in comparison with the control rats (Table 3). The predominant CLA isomers in the fat were c9t11CLA and t10c12CLA that accounted for $42.5-53.2 \%$ and $27.4-34.9 \%$ of the concentration sum of all assayed CLA isomers ( $\mathrm{CLLA}$ ) in the fat of rats fed the diet enriched in CLAmix with or without Se (as SeIV or SeY). The concentration of $c 9$ t11CLA in the fat was highly significantly higher $(\mathrm{P}<0.01)$ compared with the concentration of other isomers (i.e.: $t 10 c 12 \mathrm{CLA}, c 9 c 11 \mathrm{CLA}$ and $t 7 c 9 \mathrm{CLA}$ ) in the fat of rats fed the diet containing CLAmix, regardless of the addition of SeIV or SeY. Moreover, the addition of $0.5 \mathrm{ppm}$ Se as SeIV, 0.2 or $0.5 \mathrm{ppm}$ Se as SeY to the diet enriched in CLAmix resulted in a significantly higher concentration of $c 9 t 11 \mathrm{CLA}, t 7 c 9 \mathrm{CLA}$, t10c12CLA and $c 9 c 11$ CLA in the fat $(\mathrm{P}<0.01)$ than in the fat of rats fed the diet containing only CLAmix. Our current studies are in agreement with our previous results showing that dietary $2 \mathrm{ppm}$ Se as selenate stimulated the accumulation of CLA isomers in the liver and femoral muscles of rats fed a diet enriched in 1 or 2\% CLA isomers (Czauderna et al., 2003, 2004). Considering the above, we argue that dietary inorganic Se-compounds (i.e. selenate or selenite) and organic Se-compounds (mainly Se-Met) have a similar effect on the accumulation of CLA isomers in selected tissues of rats. The results of our study also demonstrate that the accumulation of $c 9 t 11$ CLA and $t 10 c 12$ CLA in fat was selective. Therefore, the ratios $\left(\mathrm{R}_{c t t l l \mathrm{CLA} / t \mid 0 c 12 \mathrm{CLA}}\right)$ of these isomers in the fat of rats fed the diet containing CLAmix (irrespective of the presence of SeIV or SeY) were higher (1.5213 1.6213) in comparison with the ratios of these isomers in the CLA isomer mixture added to the rat diets (i.e. $\mathrm{R}_{c 9 t 1 / \mathrm{CLA} / t 10 c / 2 \mathrm{CLA}}=0.9879$ ). Thus, our studies documented that $t 10 c 12$ or $t 10 t 12$ isomers of CLA were more efficiently driven through $\beta$-oxidation in the abdominal fat than their 9,11 homologues (Alasnier et al., 2002; Banni et al. 2004). On the other hand, accumulated c9t11CLA could then be metabolized to long-chain conjugated fatty acids (e.g. $c 8 c 1 t 13 \mathrm{C} 20: 3$, $c 8 t 12 c 14 \mathrm{C} 20: 3, c 5 c 8 c 11 t 13 \mathrm{C} 20: 4$ or $c 5 c 8 t 12 c 14 \mathrm{C} 20: 4)$ using the same pathway as linoleic acid (i.e. via desaturation and elongation pathways) (Belury, 2002; Czauderna et al., 2003, 2004). As can be seen from the results in Table 3, the increase in the ratio of these isomers was highest $(\mathrm{P}<0.05)$ in the fat of rats fed the diets enriched in CLAmix and ${ }_{\mathrm{H}} \mathrm{SeY}$ than in the fat of animals fed the diet containing CLA with or without ${ }_{\mathrm{L}} \mathrm{SeIV},{ }_{\mathrm{H}} \mathrm{SeIV}$ or ${ }_{\mathrm{L}} \mathrm{SeY}$ (1.6213 vs. 1.5211, 1.5495, 1.5078 and 1.5263 , respectively).

The present trial has demonstrated that the addition of CLAmix to the diet, regardless of the presence of SeIV or SeY, increased the concentration ratios of PUFAn-6/PUFAn-3 in the fat $(\mathrm{P}<0.01)$ compared with rats fed the diets enriched in SeIV or SeY. On the other hand, the diet containing ${ }_{\mathrm{H}} \mathrm{SeIV},{ }_{\mathrm{L}} \mathrm{SeY}$ or ${ }_{\mathrm{H}} \mathrm{SeY}$ decreased the values of this ratio in the fat in comparison with the control group 
$(\mathrm{P}<0.05, \mathrm{P}<0.01$ and $\mathrm{P}<0.01$, respectively). The diets enriched in $0.2 \mathrm{ppm}$ SeIV numerically or statistically $(\mathrm{P}<0.05)$ increased the values of the concentration ratios of PUFA/SFA, MUFA/SFA, UFA/SFA, and PUFA/FA in the fat compared with the control group. On the other hand, other experimental diets (Table 4) resulted in inconsistent and negligible changes of the values of these ratios in the fat in comparison with the control group. Considering the values of the above ratios as well as A-SFA T-SFA (Table 3), we suggest that supplementing the diet with $0.2 \mathrm{ppm}$ SeIV most effectively improves the nutritional value of fat tissues of monogastric animals.

The effect of the experimental diets on the fatty acid profile in the brain of rats. Our investigation of the effect of 6 weeks of feeding the experimental diets showed that dietary CLA isomers or Se, regardless of its chemical form and level in the diet, had a substantial influence on the abundance of all determined fatty acids in the brain (Tables 5 and 6). Indeed, these diets significantly reduced $(\mathrm{P}<0.01)$ the concentration of $\mathrm{C} 14: 0, \mathrm{C} 16: 0, \mathrm{C} 18: 0, c 9 \mathrm{C} 18: 1, \mathrm{LA}, \alpha \mathrm{LNA}$, c11c14c17C20:3, c8c11c14C20:3, c5c8c11c14C20:4, c7c10c13c16c19C22:5, $c 4 c 7 c 10 c 13 c 16 c 19 \mathrm{C} 22: 6$, as well as SFA, A-SFA, T-SFA, MUFA, all polyunsaturated FA (i.e. PUFAn-3, LPUFAn-3, PUFAn-6, LPUFAn-6) in the brain in comparison with the control group. Similarly, the diet enriched in CLAmix and $\mathrm{Se}\left(\right.$ as ${ }_{\mathrm{L}} \mathrm{SeIV},{ }_{\mathrm{H}} \mathrm{SeIV},{ }_{\mathrm{L}} \mathrm{SeY}$ or ${ }_{\mathrm{H}} \mathrm{SeY}$ ) significantly decreased the concentration of these fatty acids in the brain (for the interactions: $\mathrm{P}<0.01$ ). As can be seen from the results summarized in Tables 2 and 5, the decrease in the concentration sum of fatty acids ( $\Sigma F A)$ in the brain of rats fed the diet containing Se as SeIV or SeY, irrespective of the presence of CLAmix, was accompanied by decreases in brain mass compared with the control animals.

Unfortunately, the values of the PUFAn-6/PUFAn-3 ratio numerically or statistically significantly increased in the brain of rats fed the diet containing 0.2 ppm SeIV ( $\mathrm{P}=0.46), 0.5 \mathrm{ppm}$ SeIV $(\mathrm{P}=0.59), 0.2 \mathrm{ppm} \mathrm{SeY}(\mathrm{P}=0.0008), 0.5 \mathrm{ppm}$ $\mathrm{SeY}(\mathrm{P}=0.0063)$ or CLAmix $(\mathrm{P}=0.027)$ in comparison with the control group. Moreover, the values of the ratio of PUFA/SFA, MUFA/SFA, UFA/FA and PUFA/ FA were significantly higher $(\mathrm{P}<0.01)$ in the brain of rats fed the diet with only the one additive (Table 6) than in the control group. There were CLAmix x Se interaction effects $(\mathrm{P}<0.01)$ on the values of these ratios in the brain of rats fed the diet containing CLAmix and Se (as SeIV or SeY) with the exception of the diet enriched in CLAmix and $0.2 \mathrm{ppm}$ Se as SeIV; feeding the diet containing both CLAmix and Se, regardless of the level and chemical form of Se, resulted in a major decrease in the values of these ratios (ca. 50-150\%) compared with the control group. As can be seen from the data presented in Tables 5 and 6, the diet enriched in CLAmix or Se (as SeIV or SeY) decreased the capacity of $\Delta 9$-desaturase $(\mathrm{P}<0.01)$ compared with the control rats; there were CLAmix x Se 


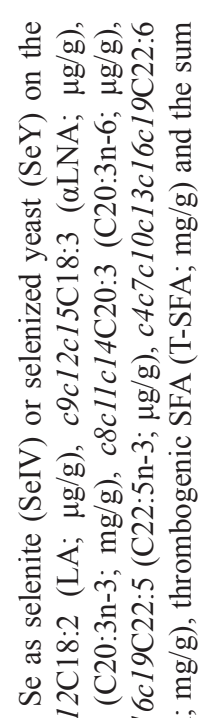

अवे m.

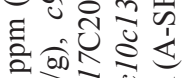

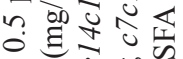
50 ○讨 ह टू कि 른 กै क्षि

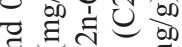
(1)

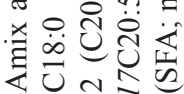

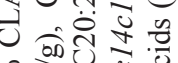

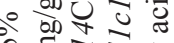

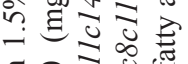
g. 0 \%

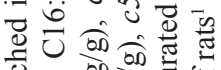

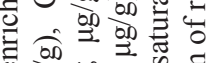
ob

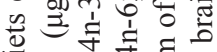

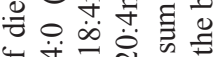

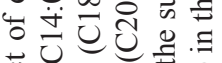
क्ष

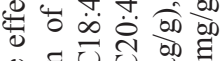
o 응 원 类 的娄

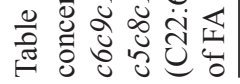

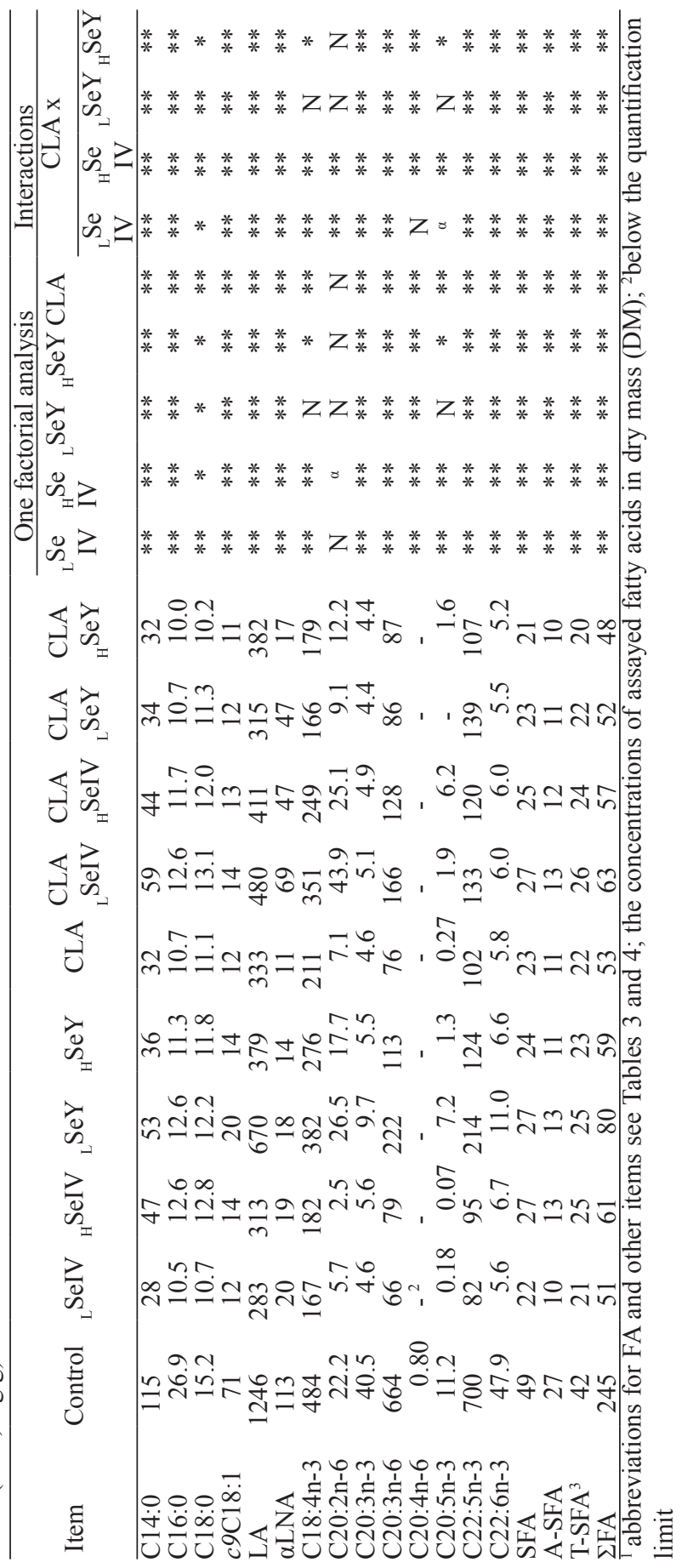




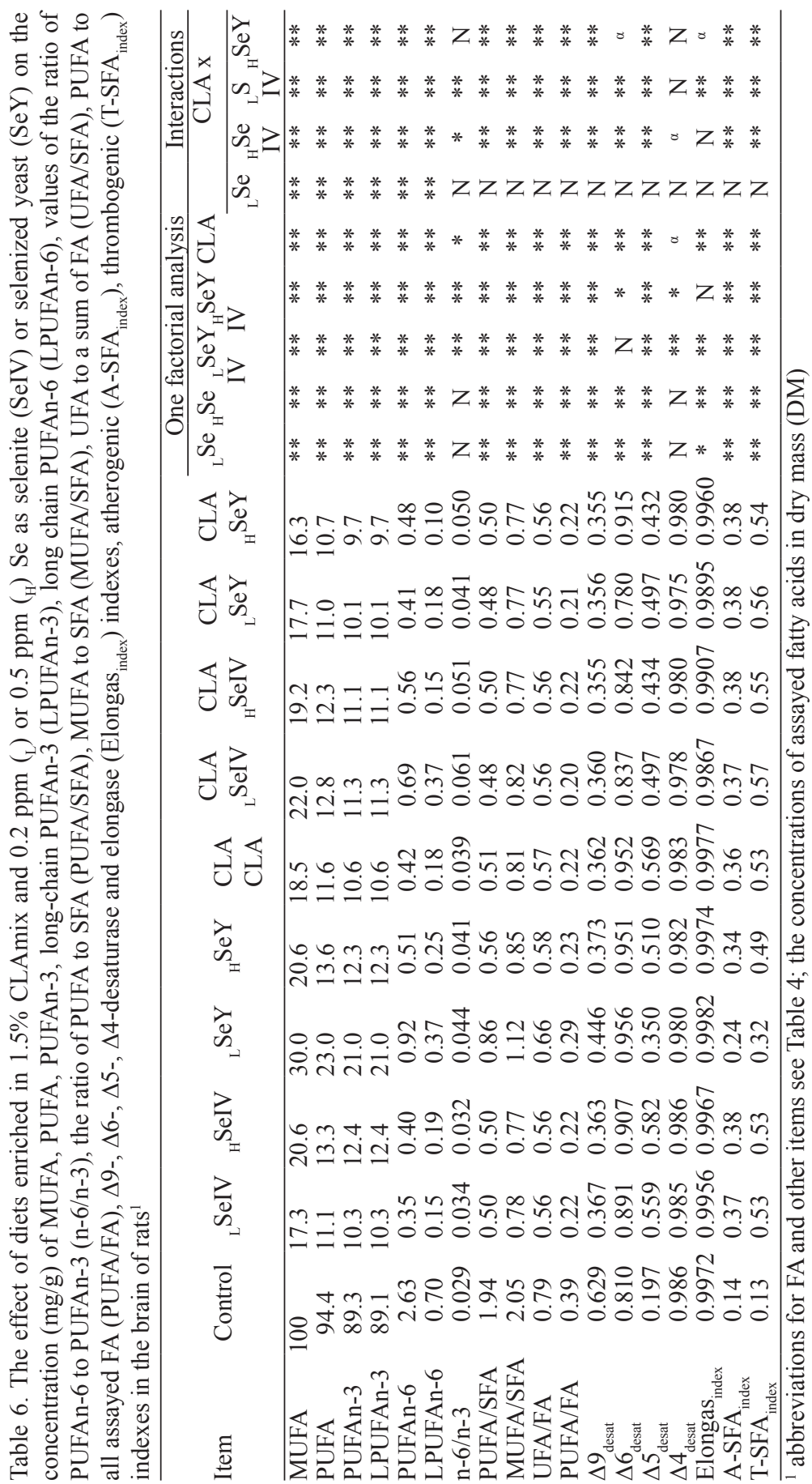


as $\mathrm{SeY}, 0.5 \mathrm{ppm}$ Se as $\mathrm{SeIV}$ or $\mathrm{SeY})$ interaction effects $(\mathrm{P}<0.01)$. The simultaneous supplementation of CLAmix and Se, regardless of the level and chemical form of $\mathrm{Se}$ in the diet, resulted in a decrease in the capacity of $\Delta 9$-desaturation (ca. $44 \%$ ) in comparison with the control group. On the other hand, the diet containing only CLAmix, SeIV or SeY, irrespective of the extra Se level in the diet, significantly increased $(\mathrm{P}<0.01$ or $\mathrm{P}<0.05)$ the capacity of $\Delta 6$ - and $\Delta 5$-desaturase in the brain. There were CLAmix $x$ Se interaction effects $(\mathrm{P}<0.01)$ on the capacity of these desaturases in the brain of rats fed the diet containing CLAmix and Se (as SeIV or $\mathrm{SeY}$ ) with the exception of the diet enriched in CLAmix and ${ }_{\mathrm{L}} \mathrm{SeIV}$. The diet enriched in CLAmix, $\mathrm{SeY}$ (as ${ }_{\mathrm{L}} \mathrm{SeY}$ or ${ }_{\mathrm{H}} \mathrm{SeY}$ ) decreased the capacity of $\Delta 4$-desaturase in the brain; the simultaneous addition of CLAmix and Se (as SeIV or SeY) to the diet resulted in a decrease in the values of this desaturase, although there were no statistically significant interaction effects $(\mathrm{P}>0.05)$. The diet enriched in SeIV (as ${ }_{\mathrm{L}} \mathrm{SeIV}$ or ${ }_{\mathrm{H}} \mathrm{SeIV}$ ), irrespective of the presence of CLAmix, decreased the value of the elongase index in the brain, while addition of CLAmix or SeY (as ${ }_{L} \mathrm{SeY}$ or ${ }_{\mathrm{H}} \mathrm{SeY}$ ) increased the index value in comparison with the control group.

Unfortunately, all experimental diets increased $(\mathrm{P}<0.01)$ the atherogenic and thrombogenic indexes in the brain; only in the brains of rats fed the diet enriched in CLAmix and ${ }_{L}$ SeIV were the interaction effects on these indexes statistically insignificant.

\section{CONCLUSIONS}

Rations enriched in selenite, selenized yeast (up to $0.5 \mathrm{mg}$ total dietary Se/ $\mathrm{kg}$ diet) and CLA isomers (up to 1.5\%) can be regularly used to increase the concentration of Se and CLA isomers in monogastric farm animals without adversely influencing performance. The present study demonstrated that the addition of 0.2 or $0.5 \mathrm{ppm} \mathrm{Se}$ as SeIV or SeY to the diet, irrespective of the presence of CLAmix, had a beneficial effect on body mass accretion, as well as feed conversion efficiency in rats. Moreover, dietary inorganic (as selenate or ${ }_{\mathrm{H}} \mathrm{SeIV}$ ) or organic (as Se-Met) Se-compounds stimulated the bioassimilation of CLA isomers in selected tissues of rats. Feeding rats with the diet enriched in 0.5 ppm Se (as SeIV or SeY) with or without CLAmix improved the nutritive value of the abdominal fat because the concentration of LPUFAn-3 increased, while the PUFAn-6/PUFAn-3 ratio decreased in the fat of rats fed the diet containing SeY in particular. Finding that diets enriched in 1.5\% CLA isomers and $0.2 \mathrm{ppm}$ Se (as SeY) or $0.5 \mathrm{ppm}$ Se (as SeIV) most effectively increased the concentration of CLA isomers in the abdominal fat, as well as efficiently elevated body weight accretion and feed conversion efficiency in rats is valuable information for 
nutritionists carrying out research to improve the nutritive value of food derived from monogastric farm animals for human health.

\section{REFERENCES}

Alasnier C., Berdeaux O., Chardigny J.M., Sébédio J.L., 2002. Fatty acid composition and conjugated linoleic acid content of different tissues in rats fed individual conjugated linoleic acid isomers given as triacylglycerols. J. Nutr. Biochem.13, 337-345

Arteel G.E., Sies H., 2001. The biochemistry of selenium and gluthatione system. Environ. Toxicol. Pharmacol. 10, 153-158

Banni S., Petroni A., Blasevich M., Carta G., Angioni E., Murru E., Day B.W., Melis M.P., Spad S., Clement C., 2004. Detection of conjugated C16 PUFAs in rat tissues as possible partial betaoxidation products of naturally occurring conjugated linoleic acid and its metabolites. Biochim. Biophys. Acta 1682, 120-127

Belury M.A., 2002. Dietary conjugated linoleic acids in health: Physiological effects and mechanisms of action. Annu. Rev. Nutr. 22, 505-531

Crespo A.M., Reis M.A., Lanca M.J., 1995. Effect of selenium supplementation on polyun-saturated fatty acids in rats. Biol. Tr. Elem. Res. 47, 335-341

Czauderna M., Kowalczyk J., Korniluk K., Wąsowska I., 2007. Improved saponification then mild base and acid-catalyzed methylation is a useful method for quantifying fatty acids, with special emphasis on conjugated dienes. Acta Chromatogr. 18, 59-71

Czauderna M., Kowalczyk J., Krajewska K.A., Rozbicka A.J., Michalski J., 2009. Dietary selenite and conjugated linoleic acid isomers influence fatty acid concentrations in the liver and femoral muscles of rats. J. Anim. Feed Sci. 18, 564-581

Czauderna M., Kowalczyk J., Niedźwiedzka K.M., Wąsowska I., Pastuszewska B., 2004. Conjugated linoleic acid (CLA) content and fatty acids composition of muscle in rats fed isomers of CLA and selenium. J. Anim. Feed Sci. 13, 183-196

Czauderna M., Kowalczyk J., Wąsowska I., Niedźwiedzka K.M., Pastuszewska B., 2003. The effects of selenium and conjugated linoleic acid (CLA) isomers on fatty acid composition, CLA isomer content in tissues, and growth of rats. J. Anim. Feed Sci. 12, 865-881

Dumont E., Vanhaecke F., Cornelis R., 2006. Selenium speciation from food source to metabolites: a critical review. Anal. Bioanal. Chem. 385, 1304-1323

Hinojosa L., Ruiz J., Marchante J.M., Gacía J.I., Sanz-Medel A., 2006. Selenium bioaccessibility assessment in selenized yeast alter 'in vitro' gastrointestinal digestion using two-dimensional chromatography and mass spectrometry. J. Chromatogr. A 1110, 108-116

Hur S.J., Park G.B., Joo S.T., 2007. Biological activities of conjugated linoleic acid (CLA) and effects of CLA on animal products. Livest. Sci. 110, 221-229

McDowell L.R., Davis P.A., Cristaldi L.A., Wilkinson N.S., Buergelt C.D., Van Alstyne R., 2005. Toxicity of selenium: fear or precaution? Feedstuffs $77(22), 12-13$

Navarro-Alarcon M., Cabrera-Vique C., 2008. Selenium in food and the human body: A review. Sci. Total Envir. 400, 115-141

Olendorf H.M., 2002. The birds of Kesterson Reservoir: a historical perspective. Aquatic Toxicol. 57(1-2), 1-10

Park Y., Pariza M.W., 2007. Mechanisms of body fat modulation by conjugated linoleic acid (CLA). Food Res. Int. 40, 311-323

Pastuszewska B., Ochtabińska A., Morawski A., 2000. A note on the nutritional adequacy of stock diets for laboratory rats and mice. J. Anim. Feed Sci. 9, 533-542 
Thomson C.D., 2004. Assessment of requirements for selenium and adequacy of selenium status: a review. Eur. J. Clin. Nutr. 58, 391-402

Tinggi U., 2003. Essentiality and toxicity of selenium and its status in Australia: A review. Toxicol. Lett. 137, 103-110

Ulbricht T.L.V., Southgate D.A.T., 1991. Coronary heart disease: seven dietary factors. Lancet 338, 985-992

Wolffram S., 1999. Absorption and metabolism of selenium: differences between inorganic and organic sources. In: T.P. Lyons, K.A. Jacques (Editors). Biotechnology in the Feed Industry. Nottingham University Press, Nottingham, pp. 547-566

Zagrodzki P., Bik D., Fitak B.A., Suchocki P., Niemczuk K., 2000. Selenoenzymes in animal tissues after supplementation with selol. Bull. Vet. Inst. Pulawy 44, 215-220 